\title{
Analysis of the Phytochemical Characteristics of Jasmine Flower Crude Extract against Escherichia coli and Staphylococcus aureus
}

\author{
NATHASA WEISDANIA SIHITE ${ }^{1}$, HERLA RUSMARILIN ${ }^{2}$, AND MANUNTUN ROTUA $^{1}$ \\ ${ }^{I}$ Nutrition department, Health Polytechnic Palembang, Palembang, Indonesia; \\ ${ }^{2}$ Food technology department, Universitas Sumatera Utara, Medan, Indonesia.
}

\begin{abstract}
Indonesia is a famous country whose high diversity of plants, especially agricultural product and herbs, which has a potential of antimicrobial such as like Jasmine flower (Jasminum sambac (L.) Ait). Previous research discovered the presence of active compound that could inhibit bacterial growth. This study aimed to determine the phytochemical and antimicrobial activity of Jasmine flower. The crude extraction was obtained by maceration, using water solvent, methanol, ethyl acetate, and n-hexane as the solvent; respectively. The inhibition assay of pathogenic microbes (Escherichia coli and Staphylococcus aureus) was conducted using the dilution method. The sample bacteria used were Escherichia coli (ATCC 8938) and Staphylococcus aureus (ATCC 6538). This study used disc diffusion method, with a complete 2-factor random design and 4 replications. Data processing was conducted using ANOVA. The results showed that the Jasmine extracts with a concentration of 25\%, 50\%, 75\% and $100 \%$ had an effect to inhibit of the growth of the bacteria. The extract with ethyl acetate solvent was the most effective in inhibiting the growth of bacteria. The results showed that jasmine flower extract contained alkaloids, flavonoids, steroids, saponins, tannins, and phenolics. Minimum Inhibitor concentration (MIC) occurred at concentrations of $0.1 \%$ and $0.25 \%$ of Jasmine extract on Staphylococcus aureus and Escherichia coli, respectively. Phytochemical content contained in Jasmine flower extracts by literature study has the potential as an antimicrobials and needs to be proven by further research.
\end{abstract}

Key words: antimicrobials, Escherichia coli, jasmine, Sthaphylococcus aureus

Indonesia merupakan negara yang terkenal dengan keanekaragaman hayati khususnya tanaman dan herbal yang memiliki potensi antimikroba seperti bunga Melati (Jasminum sambac (L.) Ait). Penelitian sebelumnya menemukan adanya senyawa aktif yang dapat menghambat pertumbuhan bakteri. Penelitian ini bertujuan untuk mengetahui aktivitas fitokimia dan antimikroba bunga melati. Ekstraksi dilakukan dengan cara maserasi dengan menggunakan pelarut air, metanol, etil asetat, dan heksana sebagai pelarut. Pengujian ekstrak dilakukan dengan metode pengenceran. Sampel bakteri yang digunakan adalah Escherichia coli (ATCC 8938) dan Staphylococcus aureus (ATCC 6538). Penelitian ini menggunakan metode difusi cakram, dengan rancangan acak lengkap 2 faktor dan 4 ulangan. Pengolahan data dilakukan dengan menggunakan ANOVA. Hasil penelitian menunjukkan bahwa ekstrak melati dengan konsentrasi 25\%,50\%,75\% dan 100\% berpengaruh dalam menghambat pertumbuhan bakteri. Ekstrak bunga melati dengan pelarut etil asetat paling efektif untuk menghambat pertumbuhan bakteri. Hasil penelitian menunjukkan bahwa ekstrak bunga melati mengandung alkaloid, flavonoid, steroid, saponin, tanin dan fenolik. Minimum Inhibitor Concentration (MIC) terdapat pada konsentrasi 0,1\% (Staphylococcus aureus) dan 0,25\% (Escherichia coli). Kandungan fitokimia yang terdapat pada ekstrak bunga melati secaja kajian memiliki potensi sebagai antimikroba dan perlu dibuktikan dengan penelitian lebih lanjut lagi.

Kata kunci: antimikroba, bunga melati, Escherichia coli, Sthaphylococcus aureus

Jasmine flower is a commodity with high economic value, its utility is not only as potted and garden ornamental plants, but also as tea fragrance, raw material perfume industry, cosmetics, traditional medicine, flower sow tomb, room decoration, and complements in traditional ceremonies (Sihite et al. 2018). There are different sorts of jasmine blooms, but the one commonly found is white jasmine (Jasminum sambac (L.) Ait.). Jasmine blossoms are utilized as a crude fabric for the fabricating preparation of jasmine

*Corresponding author: Phone: +62-81362007718; E-mail: weisdania@gmail.com oil (outright), which is utilized within the cleanser, corrective, pharmaceutical, fragrance, fragrance-based treatment, and spa businesses. Jasmine blossoms are too frequently utilized as an added substance in making tea (Tahir et al. 2017). Jasminum sambac species is the foremost popular species in Indonesia and has been named the nation's puspa flowers.(Suyanti et al. 2003). Jasmine flowers have been known for a long time as a traditional medicinal ingredient including for the treatment of asthma, ulcers, and joint pain (Patil and Patil 2011). The flowers, leaves, and stems of jasmine contain various chemical components such as alkaloids, glycoside, saponins, terpenoids, and 
flavonoids which are often used in the field of pharmacological research (Sabharwal et al. 2013). The flavonoids which function as antioxidants and have an antibacterial function in the wound healing process (Ridwan Rais 2015). The content of active compounds found in jasmine flowers such as alkaloids, flavonoids, saponins and tannins can function as antiseptics and antioxidants and are believed to be used as antibacterial (Krishnaveni and Thaakur 2012). The methanol extract of jasmine flowers when tested using the disc diffusion method and the dilution method had antimicrobial activity against various types of bacteria such as Salmonella enteric, Enterococcus faecalis, Streptococcus pyogenes, and Bacillus cereus (AbdoulLatif et al. 2011). According to research conducted by (Al-hussaini and Mahasneh 2011) showed that in testing the antibacterial and antifungal activity of jasmine flower extracts produced a larger diameter of the inhibition zone when compared to jasmine flower leaves. Natural preservation by utilizing plants is an alternative. Some plants contain antimicrobial compounds that can be used to inhibit growth and kill pathogenic microbes, one of which is jasmine. The types of microbes studied in this study are pathogenic bacteria that can cause various diseases in humans, such as diarrheal disease by Escherichia coli, boils, skin infections ulcers by Staphylococcus aureus (Jayalandri et al. 2016). The use of jasmine flowers in industrial technology, especially in the food industry, needs to be followed up, therefore it is necessary to do further research on jasmine flower extract (J. sambac) which is used as a natural antimicrobial ingredient for the food industry. It is hoped that this natural extract from jasmine flowers can be used as an alternative to preservatives and natural antimicrobials in inhibiting microbial growth. Based on this background, it is necessary to research jasmine flower extract as a natural antimicrobial ingredient. The purpose of this research is to extract the antimicrobial active compound in the jasmine flower and see its effect in inhibiting the growth of microbes Escherichia coli and Staphylococcus aureus and see whether jasmine extract can be an alternative as natural preservatives so that it can replace the many synthetic preservatives that are synthetic preservatives circulating in society

\section{MATERIALS AND METHODS}

Plant Material. The material used is fresh jasmine flowers with the criteria of semi-blooming florets obtained from traditional farmers in the Sei-Mencirim area, Medan Tuntung District, North Sumatra. Chemicals and media, namely nutrient agar (NA), Mueller Hinton Agar (MHA), Nutrient Broth (NB), dimethyl sulfoxide (DMSO), $\mathrm{NaCl} 0,9 \%$, distilled water, disc paper (Oxoid), , water, methanol, ethyl acetate and $n$-hexane. The material used for bacterial test was Plate Count Agar (PCA). Equipment used in this study were laminar air flow cabinet (Astec HLF 1200L), analytical balance (Mettler Toledo), autoclave (Express), refrigerator (Toshiba), micrometer pipettes (Eppendorf), oven (Memmert), incubator, rotary evaporator (Stuart), oxoid paper and colony counter. Bacterial cultures used in the study were Staphylococcus aureus (ATCC 6538), Escherichia coli (ATCC 8938).

Jasmine Flower Extract. Jasmine flower were washed and dried in the oven at $40^{\circ} \mathrm{C}$ for $48 \mathrm{~h}$. Jasmine flower powder then weighed 480 grams each and then macerated with four types of solvents (water, methanol, ethyl acetate and n-hexane) for 3 days. The dried powder jasmine was divided into 4 groups of 480 grams powder and dissolved with solvent (water, methanol, ethyl acetate and n-hexane) in a erlenmeyer then macerated for $72 \mathrm{~h}$ and shaking periodically. The precipitated residue was separated from the solvent by filtration and concentrated by using vacuum evaporator at $50{ }^{\circ} \mathrm{C}$ to produce a crude extract. The extract was then weighed and obtained the results of jasmine flower extract from each solvent, namely: jasmine flower extract with water solvent (19 g), jasmine flower extract with methanol (49.1 g), jasmine flower extract with ethyl acetate solvent (11.6 g), and jasmine flower extract with $\mathrm{n}$-hexane solvent $(6.9 \mathrm{~g})$. Qualitative phytochemical test were carried out on the extracts obtained to determine the presence of several chemical compounds by the method of Indonesian Ministry of Health(Indonesia Ministry of Health 1995) and Fransworth (Fransworth 1996) included alkaloids, flavonoids, steroids, saponins, tannins and phenols.

Antimicrobial Activity. The microbial growth inhibitory potential of the crude extract was determined using disk diffusion method described by Kirby-Bauer (Kirby et al. 1966). To testing the crude extract used blank disc paper with a diameter of $6 \mathrm{~mm}$. The disc is inserted into a sterile empty petri dish. Preparation of stocks solution ( $100 \%$ extract) was done by dissolved $2 \mathrm{~g}$ of each extract into $2 \mathrm{ml}$ DMSO (Dimethyl Sulfoxide). Furthermore, the stock solution was reconstituted with DMSO to obtain $75 \%, 50 \%$ and $25 \%$ of extract concentration. The tested organisms used Escherichia coli (ATCC 8938) and 
Staphylococcus aureus (ATCC 6538) were obtained from Microbiology Laboratory, Faculty of Pharmacy, North Sumatera University and were performed by agar disc-diffusion method by Balouiri (Balouiri et al. 2016). Filter paper disc containing jasmine extracts from different solvents $(25 \%, 50 \%, 75 \%$ and $100 \%)$ were placed on the agar surfaces (Mueller-Hinton Agar). The culture was incubated at an optimum temperature of $37-38^{\circ} \mathrm{C}$ for $24 \mathrm{~h}$. After the incubation period, the diameter of the inhibitory zone (clear area) around the disc is measured using a calipers. The activity of extract can be seen with the inhibition zone around the disc.The clear area around the disc paper shows a positive test for inhibition of bacterial growth (Hombach et al. 2013). The minimum inhibitory concentrations (MIC) of jasmine extract was performed by a serial dilution technique $(0.025,0.05$, $0.1,0.25,0.5,1.0,2.0$, and $3.0 \%$ ) of the concentrates (Brenes et al. 2007). As much $10 \mu \mathrm{L}$ of bacteria test culture were mixed with jasmine extract (the best extract of several solvent) and shaken using shaker incubator at speed $150 \mathrm{rpm}$ for 24 hours. The diameters of the inhibition zones were measured in $\mathrm{mm}$ and the minimum extract concentration that inhibits $90 \%$ of the growth of bacteria known as MIC (Thaweboon and Thaweboon 2018).

Assay Method. The study was conducted in 3 stages. The first step is the phytochemical test of jasmine flower extract on various types of solvents, namely water, methanol, ethyl acetate, and hexane. Phytochemicals test such as alkaloids, steroids/terpenoids, saponins, tannins, flavonoids, phenolics, and glycosides was done by the method of the Department of Health (Depkes 1995) and Farnsworth (1996). The second phase of the study, namely the antimicrobial test on Escherichia coli (ATCC 8938) and Staphylococcus aureus(ATCC 6538), extracts using jasmine flower extract with various concentrations, the third stage is the Minimum Inhibitory Concentration (MIC) test.

The test for the antimicrobial activity of jasmine flower extracts on Staphylococcus aureus and Escherichia coli was determined using the agar disc diffusion method (Balouiri et al. 2016). Bacteria were first incubated at $37{ }^{\circ} \mathrm{C}$ for $24 \mathrm{~h}$ in nutrient broth. The agar medium was spread with the inoculum Discs of sterile Oxoid paper of $6 \mathrm{~mm}$ in diameter are deposited on the plates. Samples in various concentrations were injected into disc of sterile Oxoid paper. After incubation at $37^{\circ} \mathrm{C}$ for $24 \mathrm{~h}$, the diameter of inhibition zone was measured in millimeters to the test organism.
Dimethyl sulfoxide (DMSO) was used as negative control. Processing of the data is using ANOVA. If the results are significantly different and very real, the test is continued with the average difference test using the LSR (Least Significant Range) test. The research study was conducted using a completely randomized design (CRD) with two factorial, consisting of solvents and concentration:

Factor I : Types of solvent (P):

P1 =Water

$\mathrm{P} 2$ = Methanol

P3 = Etyl Acetate

P4 =n-Heksane

Factor II : Concentration (K) Jasmine Extract:

$\mathrm{K} 1=25 \%$

$\mathrm{K} 2=50 \%$

$\mathrm{K} 3=75 \%$

$\mathrm{K} 4=100 \%$

Combination treatment $(\mathrm{PK})=4 \times 4=16$, for the level of accuracy, this research was conducted 4 times.Completely Randomized Design (RAL) Model used as below:

$$
Y i j k=\mu+\alpha i+\beta j+(\alpha \beta) i j+\varepsilon i j k
$$

\section{RESULT}

Yield of Jasmine Extraction. The result of extraction with several type of solvents are shown in Table 1. The highest yield of jasmine extract was found in methanol extract and followed by water, ethyl acetate and n-hexane (Table 1). The highest yield in methanol is caused by the characteristic of methanol that can dissolve almost all of the components in polar, semi-polar and non-polar solvent(Pasaribu et al. 2015), is in according to research Benedicta and Zain (Benedicta and Zain 2016) that the methanol solvent can dissolve almost all organic compounds, both polar and non-polar because methanol has polar $(-\mathrm{OH})$ and non-polar groups (-CH).

Phytochemical Test Results. Several components of the active compounds identified in this research: alkaloids, steroids/triterpenes, saponins, tannins, flavonoids, phenolics, and glycosides. There are several bioactive compounds contained in jasmine flower extracts with water, methanol, ethyl acetate, and n-hexane as solvents (Table 2).

Based on the Qualitative phytochemical test by the method of Indonesian Ministry of Health (Indonesia Ministry of Health 1995) and Fransworth (Fransworth 1996). The test results of jasmine flower extracts in each type of solvent showed that the most optimal 
Table 1 The yield of jasmine extract

\begin{tabular}{cc}
\hline Solvent & Yield (\%) \\
\hline Water & 3,9 \\
Methanol & 10,2 \\
Ethyl acetate & 2,41 \\
n-hexane & 1,4 \\
\hline
\end{tabular}

Table 2 Phytochemical test results

\begin{tabular}{|c|c|c|c|c|}
\hline \multirow[t]{2}{*}{ Bioactive Compounds } & \multicolumn{4}{|c|}{ Solvent Jasmine Flower Extract } \\
\hline & Water & Methanol & Ethyl Acetate & n-hexane \\
\hline $\begin{array}{l}\text { Alkaloids (Indonesia Ministry of Health } \\
\text { 1995) }\end{array}$ & + & + & - & - \\
\hline Steroid/Triterpenes (Farnsworth, 1996) & + & + & + & + \\
\hline $\begin{array}{l}\text { Saponins (Indonesia Ministry of Health } \\
\text { 1995) }\end{array}$ & + & - & - & - \\
\hline Tannins & + & + & - & - \\
\hline Flavonoids & - & + & + & - \\
\hline Phenolics & + & + & + & - \\
\hline Glycosides & - & + & - & + \\
\hline
\end{tabular}

Description: $(+)=$ Contains a class of compounds $(-)=$ Does not contain compounds solvent to attract bioactive compounds is methanol. From the results of the phytochemical screening test, it is known that the n-hexane solvent contains compounds such as steroids/triterpenes, and glycosides. For ethyl acetate solvents, compounds such as steroids/triterpenes, flavonoids, and phenolics are obtained, whereas, in methanol solvents, almost all compounds can be withdrawn by methanol solvents except for saponin compounds. The research was conducted to study the different polarity solvent, including water, methanol, ethanol, ethyl acetate, and hexanes to phytochemical content and antioxidant activity of pluchea indicia less leaves extracts.

Antimicrobial Activity of Jasmine Flower Extracts against Escherichia coli and Staphylococcus aureus. The types of solvents used in jasmine flower extract had a highly significant effect (p $<0.01$ ) on the inhibition zone of $E$. coli growth. The relationship between the effect of the type of solvent on the zone diameter inhibition of the growth of $E$. coli bacteria can be seen in Fig 1 .

Each solvent has a significantly different effect. The highest inhibitory zone was obtained at ethylacetate solvent, which was $22.575 \mathrm{~mm}$, while the lowest inhibition zone diameter was obtained in methanol solvent which was $9.775 \mathrm{~mm}$. Based on the test results obtained it can be said that jasmine flowers have the ability to inhibit the growth of $E$. coli bacteria (Fig 1).
Based on the results of the study, it was found that jasmine flower extract in each concentration could inhibit the growth of $E$. coli bacteria at the lowest concentration of $25 \%$ to the highest concentration of $100 \%$. From the results of variance shows that the interaction of the type of solvent and the concentration of jasmine extract gave a very significant effect ( $P$ $<0.01)$ with the diameter of the growth inhibition zone of E. coli, so the Least Significant Range (LSR) test was continued (Fig 2).

The interaction between the types of solvents and extract concentration gives a significant effect on the diameter of the zone of growth inhibition of E. coli bacteria (Fig 2). The extract that could form the largest inhibitory zone in the three test bacteria was ethyl acetate extract. Analysis of variance showed that the type of solvent gave a very significant effect on the diameter of the growth inhibition zone of Staphylococcus aureus.

The highest inhibitory zone diameter was obtained in ethyl acetate solvent, which was $23.219 \mathrm{~mm}$, while the lowest inhibition zone diameter was obtained in methanol solvent which was $8.775 \mathrm{~mm}$ (Fig 3). The ability of the ethyl acetate solvent to inhibit the growth of Staphylococcus aureus bacteria, the greater the diameter of the inhibition zone is $23.219 \mathrm{~mm}$, while the diameter of the inhibition zone in water solvents is $14.013 \mathrm{~mm}$, in hexane solvents $13.300 \mathrm{~mm}$ and in methanol solvents is $8.775 \mathrm{~mm}$. The results of variance 
Table 2 Minimum Inhibitory Concentration (MIC) of Jasmine Extract

\begin{tabular}{ccc}
\hline Extract Concentration (\%) & Escherichia coli & Staphylococcus aureus \\
\hline 0.05 & - & - \\
0.1 & - & + \\
0.25 & + & + \\
0.5 & + & + \\
1 & + & + \\
2 & + & + \\
3 & + & + \\
4 & + & + \\
5 & + &
\end{tabular}

Description: (-) Not inhibitory zone (+) inhibitory zone

showed that the interaction of the type of solvent and the concentration of jasmine extract gave a very significant effect $(\mathrm{P}<0.01)$ with the diameter of the $S$. aureus growth inhibition zone so that the Least Significant Range (LSR) test was continued.

The highest increase in diameter of the inhibitory zone in the growth of $S$. aureus was obtained in ethyl acetate solvent which was $0.095 \mathrm{~mm}$, while the lowest increase in diameter of the inhibitory zone was obtained in the methanol solvent which was $0.011 \mathrm{~mm}$ (Fig. 4).

Minimum Inhibitory Concentration (MIC) Antimicrobial Substrate. Analysis of the mechanism antibacterial inhibition of test bacteria begins with the determination of minimum inhibitory concentration (MIC)(Yilmaz 2012). At this stage the concentration of the ethyl acetate extract used in the test was $0.05 \%$, $0.1 \%, 0.250 .5 \%, 1 \%, 2 \%, 3 \%, 4 \%, 5 \%$. The test bacteria used for the determination of MIC antimicrobial substrates are E. coli and S. aureus.

MIC test results showed that the lowest concentrations that could inhibit the growth of $E$. coli and $S$. aureus bacteria were $0.25 \%$ (E. coli) and $0.1 \%$ (S. aureus)(Table 3).

\section{DISCUSSION}

In the results of phytochemical screening, it was found that the extract of jasmine flowers with ethyl acetate solvent contained bioactive compounds, one of which was flavonoids. Flavonoids are one of the secondary metabolites produced by a plant that can be found in the leaves, tubers, roots, wood, bark, pollen, flowers, and seeds. Flavonoids in plants function to regulate growth, regulate photosynthesis, regulate antimicrobial and antiviral work, and regulate antiinsect action. This is because flavonoids have a broad spectrum of antimicrobial activity by reducing the immunity of the target organism(Davidson et al. 2014). Flavonoid compounds also could coagulate protein, flavonoid compounds are also lipophilic so that they can damage the lipid layer on the bacterial cell membrane (Tuntun 2016). According to Krishnaveni et al. (2011), there are several bioactive compounds contained in white jasmine flowers (Jasminum sambac) such as alkaloids, flavonoids, saponins, and tannins which can function as antibacterial (Krishnaveni and Thaakur 2012). In this study, almost all bioactive compounds such as alkaloids, steroids/triterpenes, saponins, tannins, flavonoids, phenolics, and glycosides are contained in the extract of jasmine flowers with various solvents with different levels of polarity. From preliminary test results of antimicrobial activity, ethyl acetate extract is the most potential extract in inhibiting the growth of E. coli and $S$. aureus. Phytochemical screening results found that jasmine flower extract with ethyl acetate solvent contains bioactive compounds, one of which is flavonoids. Flavonoids in plants function to regulate growth, regulate photosynthesis, regulate antimicrobial and antiviral work, and regulate antifungal action. This is because flavonoids have a broad spectrum of antimicrobial activity by reducing the target organism's immunity (Kuppusamy et al. 2016).

The higher concentration of the extract, the greater is the number of antimicrobial compounds such as bioactive components thus the penetration of the compound into the cell becomes easier. The research was conducted with Naufalin et al. (Naufalin 2019) research on kecombrang that has extract bioactive components functioning as an antimicrobial, so that it can inhibit the growth of microbes including Grampositive and Gram-negative bacteria .It is also according to Naufalin and Herastuti (Naufalin and Herastuti 2013) Kecombrang flower microcapsules 


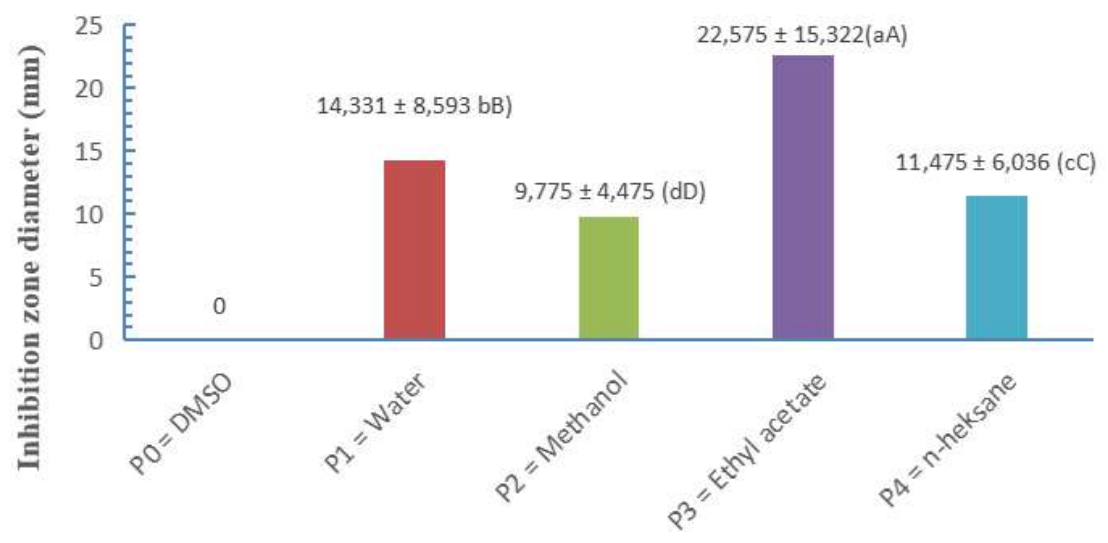

Solvent Type
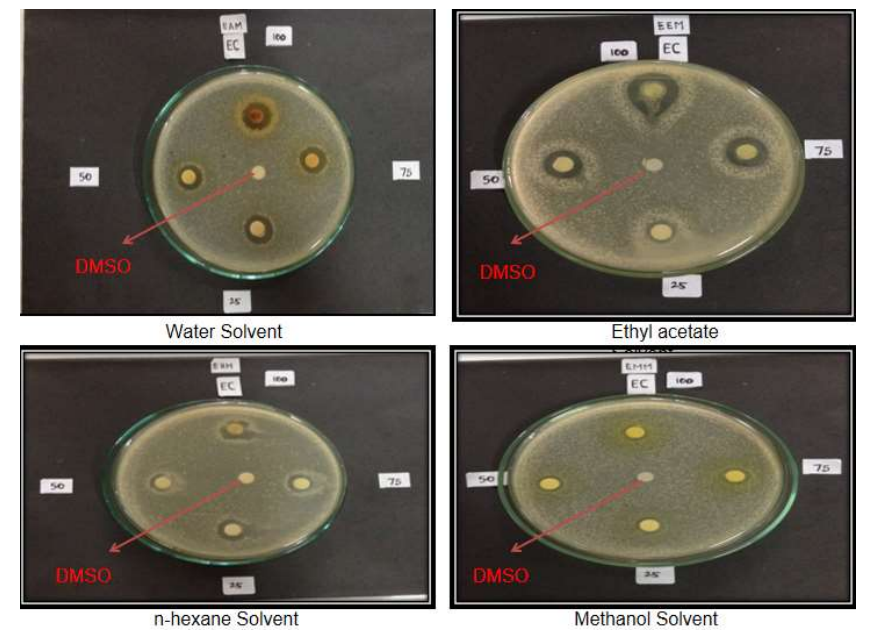

Fig 1 Effect of solvent types on diameter of inhibiting zones of Escherichia coli bacteria growth.

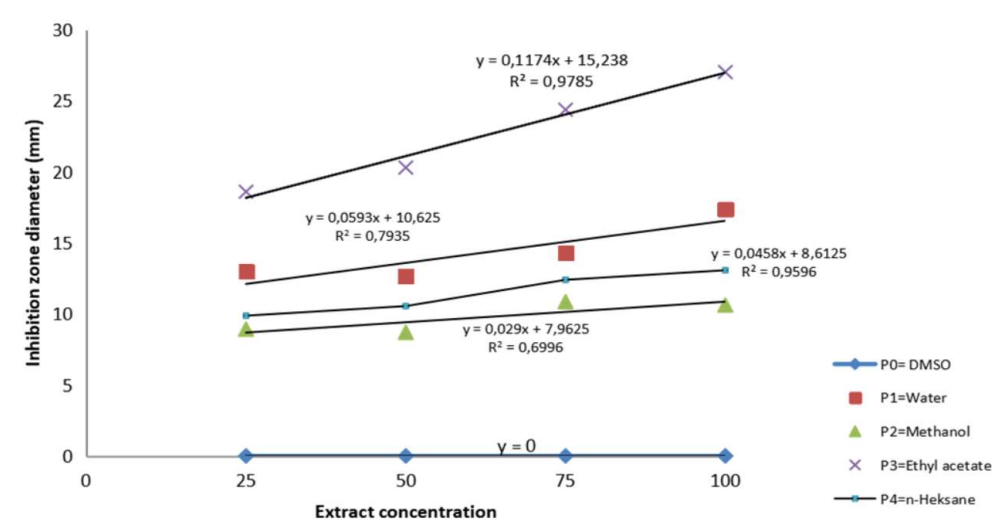

Fig 2 Interaction between types of solvents and the concentration of Jasmine extract with Escherichia coli growth inhibition zone diameter.

with ethyl acetate solvent had higher antimicrobial activity than the ethanol solvent. This is probably caused by the optimum polarity of ethyl acetate, Meanwhile, the methanol extract was not satisfactory in inhibiting Escherichia coli bacteria. This is in line with Hazimah et al., who stated in their research that methanol is a universal solvent that can dissolve most of the components of polar compounds found in Plectranthus amboinicus leaves so that the concentration of antibacterial compounds is too small or even not visible at all (Hazimah et al. 2013).

The results of variance shows that the interaction of the type of solvent and the concentration of jasmine extract gave a very significant effect $(\mathrm{P}<0.01)$ with the diameter of the growth inhibition zone of Escherichia coli. According to Eveline and Novita, that antimicrobial compound was categorized as active if the inhibition diameter is more than $6 \mathrm{~mm}$ (Eveline and 

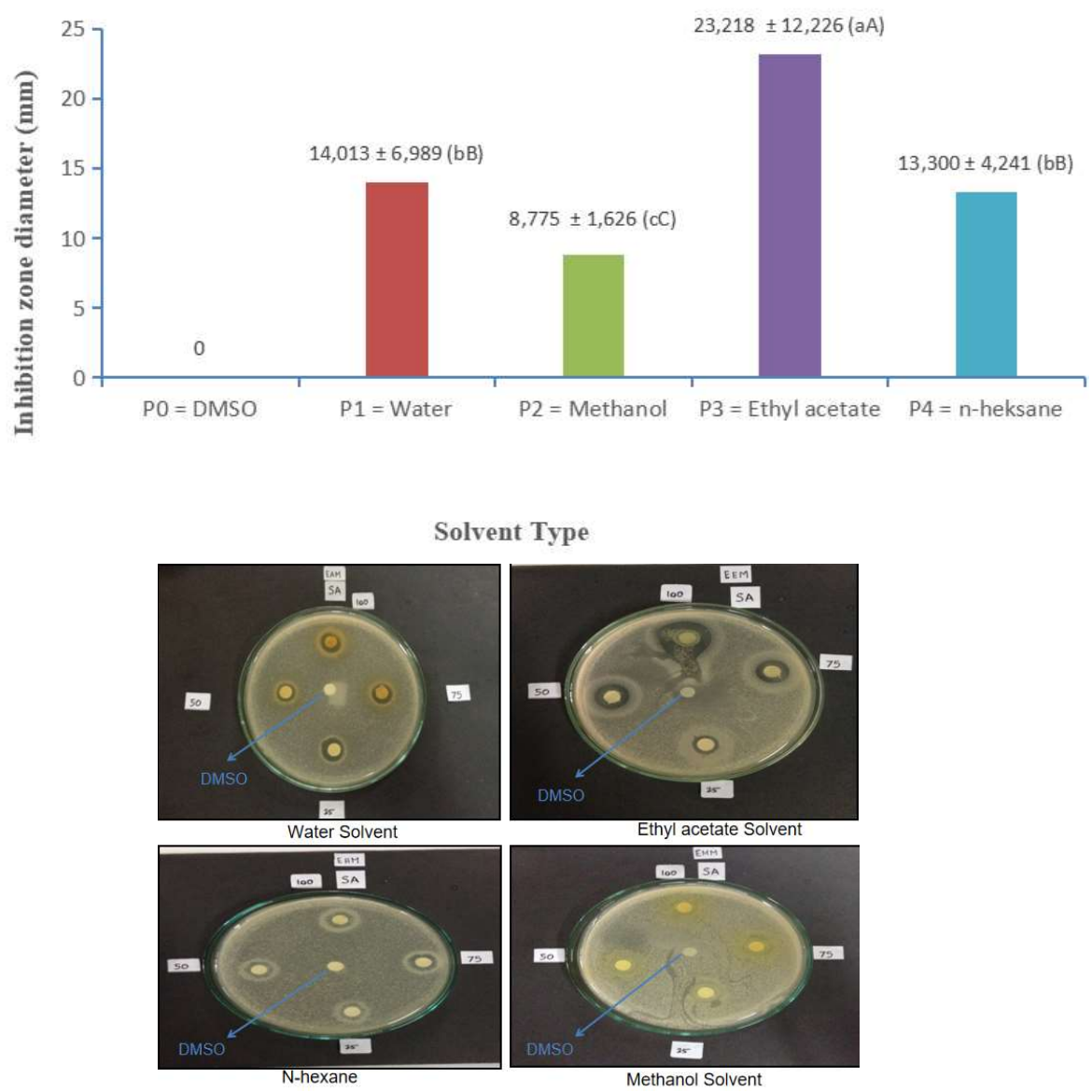

Fig 3 Effect of solvent types on diameter inhibiting zones of Staphylococcus aureus bacteria growth.

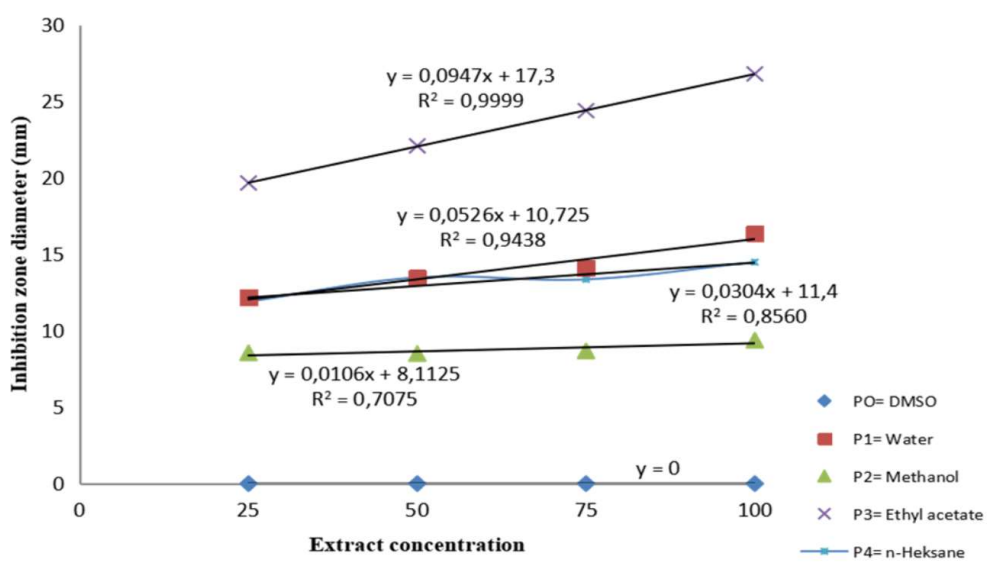

Fig 4 Interaction between types of solvents and the concentration of Jasmine Extract with Staphylococcus aureus growth inhibition zone diameter.

Novita 2020). Antibacterial activity test result show in extract using ethyl acetate was proven to be effective in inhibiting the growth of tested bacteria. Based on the results of the study it was found that DMSO did not provide inhibition toward the sample bacteria. It proved that DMSO does not have crucial role in inhibiting the growth of bacteria tested. In Figure 2, it is known that the interaction between the types of solvents and extract concentration gives a significant effect on the diameter of the zone of growth inhibition of Escherichia coli bacteria. The extract that could form the largest inhibitory zone in the three test bacteria was ethyl acetate extract. This is presumably because ethyl acetate extract has the optimum level of polarity. Based on the test results obtained it can be said that jasmine flowers have the ability to inhibit the growth of Escherichia coli bacteria. This is because the jasmine flower contains several active compounds that have the potential as natural antimicrobial agents such as flavonoids which have antibacterial activity, phenol 
compounds such as tannins, triterpenoid/steroid compounds that have antifungal activity (Lutfiyanti et al. 2012). The compounds in the polar fraction are concidered to contain many hydroxyl groups that facilitate water-soluble antibacterial compounds which can become a habitat for bacteria. Polar fraction (ethanol) is thought to have optimum polarity properties so that it diffuses more easily and can inhibit the growth of Escherichia coli. Compounds that have optimum polarity will have maximum antibacterial activity because hydrophilic-hydropobicbalance is needed (Wang et al. 2019). From the results, it can be seen that ethyl acetate solvent had a significant effect in inhibiting the growth of Staphylococcus aureus bacteria, Staphylococcus aureus is a Gram-positive bacteria. Generally, Gram-positive bacteria are more sensitive to antibacterial compounds compared to gram-negative bacteria because the cell walls of grampositive bacteria do not have a lipopolysaccharide layer so that antimicrobial compounds that are hydrophilic or hydrophobic can pass through the walls of gram-positive bacterial cells through passive diffusion mechanisms then interact directly with peptidoglycan cells bacteria that are growing and causing cell death(Ceballos et al. 2018).

Ethyl acetate solvents can be used to extract semipolar compounds such as flavonoids, phenolic, glycosides and tannins(Tanaya et al. 2015) Meanwhile, polar solvents like water can dissolve polar compounds and nonpolar compounds because it has a large dipole moment (Sulasmi et al. 2020) Phenolic is a compound that contains phenols (phenol-derived compounds) that have been chemically modified to reduce their ability to irritate the skin and increase its antibacterial activity. Antimicrobial activity of phenolic compounds is by damaging the lipids in the plasma membrane of microorganisms, causing the contents of the cell to come out (Alves et al. 2013). The results of variance showed that the interaction of the type of solvent and the concentration gave a very significant effect $(p<0.01)$ on the diameter of the Staphylococcus aureus growth inhibition zone. Figure 3 show that the highest inhibition zone on Staphylococcus aureus bacteria was found in jasmine extracted by ethyl acetate solvent with a concentration of $100 \%$, because phenolic and flavonoid compound in extracted by ethyl acetate acts as an anti-bacterial against Staphylococcus aureus (Elmasri et al. 2017). The highest inhibition zone on Escherichia coli bacteria was found in jasmine extracted by ethyl acetate solvent with a concentration of $100 \%$. Jasmine extracted by ethyl acetate contained such as steroids, phenolics and flavonoids. Steroid has antimicrobial characteristics can inhibits gram-positive and gram-negative bacteria likely Escherichia coli. The peroxide and vinyl bonds in steroids structures have a role as antibacterial, The mechanism of the effect of the sterols can be explained by the fact that they are similar to sterols that are normally used in the cells, and that they replace these substances in the cell membrane (Dogan et al. 2017). Flavonoid compounds contained in the extract have good inhibitability of Escherichia coli and Staphylococcus aureus bacteria (Wu et al. 2013). Jasmine extract used in MIC testing was extracted by ethyl acetate because ethyl acetate has been known as a good solvent for phytochemical extraction and is safe for human consumption because ethyl acetate is neither phototoxic nor photo allergenic in human tests (Shukla et al. 2019). Methanol solvent is not recommended for human, because it can cause toxicity in human such as irritating to the eyes, skin and respiratory tract, Acute oral and inhalation exposures, to a lesser extent, percutaneous absorption of high concentrations of methanol have resulted in central nervous system depression, blindness, coma and death (World Health Organization 1997). The results of the MIC value of Escherichia coli and Staphylococcus aureus are presented in Table II, The mean values of MIC jasmine extract ranged from $0.1-5 \%$. Test results showed that the lowest concentrations that could inhibit the growth of Escherichia coli and Staphylococcus aureus bacteria were $0.25 \%$ (Escherichia coli) and 0.1\% (Staphylococcus aureus).

The results of the study explained that the height and diameter zones of growth inhibition Staphylococcus aureus and Escherichia coli jasmine flower extract produced by water, methanol, ethyl acetate and $n$-hexane were caused by the properties of each solvent in attracting antibacterial compounds. The use of solvents in extracting foodstuffs will affect the results of testing the bioactive compounds of these foods. Polar compounds are more soluble in polar solvents and non-polar compounds are more soluble in non-polar solvents. Jasmine flower extract has a very significant different effect on the zone diameter of the growth inhibition of Escherichia coli and Staphylococcus aureus bacteria. Ethyl acetate has semi-polar properties that are volatile and can dissolve semipolar compounds in cell walls such as flavonoid aglycones, non-toxic and not hygroscopic. In addition, ethyl acetate can search for compounds that provide antibacterial activity, including polyhydroxy flavonoids and other phenols (Wardhani and Sulistyani 
2012). Antibacterial compounds that diffuse into the medium can inhibit the formation of thin cell walls and can lysis of the bacteria. According to suhartati et al, (2019) Flavonoids can perform inhibition mechanism by interfering with the bacterial cell wall synthesis there by causing plasma leakage resulting in lysis of the bacteria (Suhartati et al. 2019). Inhibition occurs also there is a process of protein synthesis, inhibition of protein synthesis occurs where there is a process of transcription and translation of genetic material so that the amino acids produced incorrectly place themselves in the peptide chain and produce proteins that do not function (Madigan et al. 2008). Flavonoid compounds can damage cell walls, causing cell death (Haeria and Hermawati 2016). The flavonoids are group of secondary metabolites produced by plants which is a large group of polyphenols. This compound is found in all parts of the plant, including leaves, roots, wood, and bark. Flavonoids can capture free radicals and inhibit lipid oxidation (Zuraida et al. 2017). Overall, the results of this study were examining jasmine extract the growth of Escherichia coli and, Staphylococcus aureus, and which showed the growth inhibition activity (inhibitory zone). The magnitude of the microbial growth inhibition zone examined by the extract was seen as a clear area (clear zone) around the disc. The ability of extracts to inhibit microbial growth was caused by the presence of active compounds contained in jasmine extract with various solvents. In addition to solvent types, the concentration of each jasmine extract also affected the inhibition zone diameter of Escherichia coli, and Staphylococcus aureus (Abubakar and Usman 2016). This observation is in agreement with the study of Ida Bagus, that the administration of different concentrations shows different effects on the resulting zone of inhibition. The amount of inhibition zone diameter also depends on the absorption/absorption of antibacterial substances into agar plates and the sensitivity of bacteria to these antibacterial agents (Ida Bagus 2008). Jasmine flower can be used as an alternative preservatives and pathogen control method in food material, in line with (Altemimi et al. 2019), reported a high antimicrobial activity against Staphylococcus aureus using methanol and ethanol extracts for Hopea pariviflora Beddome (Altemimi et al. 2019). The jasmine extract obtained is expected to inhibit the growth of pathogenic bacteria such as Escherichia coli and Staphylococcus aureus. This research is useful in providing information on the use of jasmine flowers as a natural resource to control microbial activity so that it has economic value and can be used in large and small scale food industries. It is hoped that further benefits of this jasmine extract will also be beneficial in other fields such as economics, pharmacy, and health.

In this research, almost all bioactive components such as: flavonoids, glycosides, triterpenes, tannins, phenolics, and glycosides are contained in flower extracts, both in water extract, methanol, ethyl acetate, and hexane. The types of jasmine flower extract with various solvents had a very significant effect $(p<0.01)$ on the inhibition of growth of Escherichia coli and Staphylococcus aureus. Ethyl acetate extract has the higher antimicrobial activity with the MIC value of $0.25 \%$ (Escherichia coli) and $0.1 \%$ (Staphylococcus aureus) Further research is needed regarding the effect of jasmine flower extract on food products that use chemicals as a preservative.

\section{REFERENCES}

Abdoul-Latif FM, Mohamed N, Edou P, Ali AA, Djama SO, Obame LC, Bassolé IHN, Dicko MH. 2011. Antimicrobial and antioxidant activities of essential oil and methanol extract of Matricaria chamomilla L. from Djibouti. J Med Plants Res. 5(9):1512-1517. doi: 10.5897/JMPR2021.7134.

Abubakar I, Usman A. 2016. Phytochemical and antibacterial investigations of moringa (Moringa oleifera) leaf extract on selected bacterial pathogens. J Microbiol Antimicrob. 8(5):28-33. doi:10.5897/jma2016.0361.

Al-hussaini R, Mahasneh AM. 2011. Antibacterial and Antifungal Activity of Ethanol Extract of Different Parts of Medicinal Plants in Jordan. Jordan J Pharm Sci. 4(1):57-69. doi: 10.1076/phbi.37.3.196.6308.

Altemimi A, Lakhssassi N, Baharlouei A, Watson DG, Lightfoot DA. 2019. Phytochemicals: Extraction, isolation, and identification of bioactive compounds from plant extracts. Plants. 6(4). doi:10.3390/plants6040042.

Alves MJ, Ferreira ICFR, Froufe HJC, Abreu RMV, Martins A, Pintado M. 2013. Antimicrobial activity of phenolic compounds identified in wild mushrooms, SAR analysis and docking studies. J Appl Microbiol. doi:10.1111/jam. 12196 .

Balouiri M, Sadiki M, Ibnsouda SK. 2016. Methods for in vitro evaluating antimicrobial activity: A review. J P h a r m A n 1. 6 ( 2): $71-79$. d o i : 10.1016/j.jpha.2015.11.005.

Benedicta N, Zain. 2016. Pengaruh Rasio Bunga Dengan Pelarut Terhadap Rendemen Dan Mutu Minyak Melati (Jasminum sambac) Menggunakan Metode Ekstraksi 
Pelarut Menguap (Solvent Extraction). [The Effect of Flower-Solvent Ratio to The Yield and Quality of Jasmine Essential Oil (Jasminum sambac) Using Solvent Extraction Method]. J Teknotan. 10(2):44-50. doi:10.24198/jt.vol10n2.7.

Brenes M, Medina E, Romero C, De Castro A. 2007. Antimicrobial activity of olive oil. Agro Food Ind Hi Tech. 18(4):6-8. doi: 10.1590/1678-457X.6508.

Ceballos S, Kim C, Ding D, Mobashery S, Chang M, Torres C. 2018. Activities of oxadiazole antibacterials against Staphylococcus aureus and other gram-positive bacteria. Antimicrob Agents Chemother. 62(8). doi:10.1128/AAC.00453-18.

Davidson PM, Taylor TM, Schmidt SE. 2014. Chemical Preservatives and Natural Antimicrobial Compounds. In: Food Microbiology.

Dogan A, Otlu S, Çelebi özgür, Kiliçle PA, Saglam AG, Can Dogan AN, Mutlu N. 2017. An investigation of antibacterial effects of steroids. Turkish J Vet Anim Sci. 41(2):302-305. doi: 10.3906/vet-1510-24.

Elmasri WA, Zhu R, Peng W, Al-Hariri M, Kobeissy F, Tran P, Hamood AN, Hegazy MF, Paré PW, MechrefY. 2017. Multitargeted Flavonoid Inhibition of the Pathogenic Bacterium Staphylococcus aureus: A Proteomic Characterization. J Proteome Res. 16(7). doi: 10.1021/acs.jproteome.7b00137.

Eveline E, Novita A. 2020. Antibacterial Potential of Star Anise (Illicium verum Hook. f.) Against Food Pathogen Bacteria. Microbiol Indones. 14(1):3. doi: 10.5454/mi.14.1.3.

Fransworth NR. 1996. Biological and Phytochemical Screening of Plants. J Pharm Sci. 22(3). doi:10.1002/jps.2600550302.

Haeria, Hermawati. 2016. Penentuan Kadar Flavonoid Total dan Aktivitas Antioksidan Ekstrak Etanol Daun Bidara (Ziziphus spina-christi L.) [Determination of Total Flavonoid Levels and Antioxidant Activity Ethanol Extract of Bidara Leaves (Ziziphus spina-christi L.)]. J Pharm Med Sci. 1(2):57-61. doi: 10.32814/jpms.v3i1.

Hazimah, Teruna HY, Jose C. 2013. Aktivitas Antioksidan dan Antimikrobial dari Ekstrak Plectranthus amboinicus [Antioxidant and Antibacterial Activity of Plectaranthus amboinicus LeafExtract]. J Penelit Farm Indonesia. 1(2):39-42. doi: 10.51887/jpfi.v10i1.

Hombach M, Zbinden R, Böttger EC. 2013. Standardisation of disk diffusion results for antibiotic susceptibility testing using the sirscan automated zone reader. BMC Microbiol. 13(1). doi: 10.1186/1471-2180-13-225.

Ida bagus D. 2008. Daya hambat fraksinasi ekstrak sembung delan (Sphaerantus indicus 1) terhadap bakteri Eschericia coli dan Staphylococcus aureus. [Inhibitid activity of plant fractination extract of Sembung Delan (Sphaeranthus indicus L.) to Eschericia coli and
Staphylococus aureus bacterial]. J Biol udayana. 12 no 2(2):74-77. doi: 10.24843/JBIOUNUD.v25.i01.

Indonesia Ministry of Health. 1995. Materia Medika Indonesia Jilid VI.

Jayalandri NLGL, Nangoy E, Posangi J, Bara RA. 2016. Uji efektivitas ekstrak melati (Jasminum sambac) pada penyembuhan luka insisi kelinci (Oryctolagus cuniculus) [Effectiveness Test Of Jasmine Extract (Jasminum sambac) On The Healing Of Rabbit Incision Wounds (Oryctolagusc cuniculus)]. J e-Biomedik. 4(1). doi: 10.35790/ebm.4.1.2016.12487.

Kirby W., Bauer A., Sherris JC, Turk M. 1966. Antibiotic susceptibility testing by standard single disk method. Am J Clin Pathol. 45. doi: 10.1093/ajcp/45.4_ts.493.

Krishnaveni A, Thaakur SR. 2012. Phytochemical Studies of Jasminum sambac. Int Res J Pharm. 2(5):95-97. doi: 10.26452/irjpas.v11i1.

Kuppusamy S, Thavamani P, Megharaj M, Nirola R, Lee YB, Naidu R. 2016. Assessment of antioxidant activity, minerals, phenols and flavonoid contents of common plant/tree waste extracts. Ind Crops Prod. 83. doi:10.1016/j.indcrop.2015.12.060.

Lutfiyanti R, ruf W, Dewi E. 2012. Aktivitas Antijamur Senyawa Bioaktif Ekstrak Gelidium latifolium Terhadap Candida albicans. [Antifungal Activity of Gelidium latifolium Extract Bioactive Compounds Against Candida albicans]. J Pengolah dan Bioteknol Has Perikan. 1(1):26-33.

Madigan M, Martinko J, Dunlap P, Clark D. 2008. Brock Biology of microorganisms 12th edn. Int Microbiol. doi:10.2436/im.v11i1.9650.

Naufalin R. 2019. Aplikasi Ekstrak Kecombrang (Nicolaia speciosa) Sebagai Pengawet Alami Tahu Pada Perajin Tahu Di Sentra Industri Tahu Desa Kalisari Banyumas [Application of Kecombrang Extract (Nicolaia speciosa) as a Natural Preservative of Tofu in Tofu Craftsmen at the Tofu Industry Center, Kalisari Village, Banyumas ]. J Abdimas. 22(2):209-214. doi:10.31294/jabdimas.

Naufalin R, Herastuti S. 2013. Microcapsule Application of Kecombrang Flower Extract : Effects of Concentration, Types of Fraction, $\mathrm{pH}$ of Medium, and $\mathrm{NaCl}$ on Microbiological Properties of Minced Beef. Anim Prod. 15(1):8-14. doi: 10.20884/1.jap.2020.22.3.77.

Pasaribu G, K. Waluyo T, Pari G. 2015. Analysis of Chemical Compounds Distinguisher for Agarwood Qualities. I n d o n e s J F R e s . 2 ( 1 ) : 1-7. doi:10.20886/ijfr.2015.2.1.644.1-7.

Patil DA, Patil PS. 2011. Folk Herbal Medicine from some Tehsils of Buldhana District (Maharashtra) in India. J E c o b i o t e c h n o 1 o g y. $3(2): 4-10$. doi:10.1016/j.jbiotec.2021.09.009.

Ridwan Rais I. 2015. Isolasi Dan Penentuan Kadar 
Flavonoid Ekstrak Etanolik Herba Sambiloto (Andrographis paniculata (BURM.F.) NESS). $\mathrm{Ph}$ a r m a c a n a. 5 ( 1 ): $100-106$. doi:10.12928/pharmaciana.v5i1.2292.

Sabharwal S, Sudan S, Vadi R. 2013. Jasminum sambac Linn (Motia): a Review. Int J Pharm Res Bio-Science. 2(5):108-130. doi:10.13040/IJPSR.0975-8232.

Shukla D, Singh S, Parveen S, Gupta M, Shukla JP. 2019. Acoustical properties of binary mixtures of heptane with ethyl acetate or butyl acetate. Chinese J Chem. 28(3):371-377. doi:10.1002/cjoc.201090081.

Sihite NW, Rusmarilin H, Suryanto D, Sihombing DR. 2018. Utilization of jasmine flower extract as antimicrobial in tempeh sausage. In: IOP Conference Series: Earth and Environmental Science. Vol. 205.

Sri Widyawati P, Budianta TDW, Kusuma FA, Wijaya EL. 2014. Difference of solvent polarity to phytochemical content and antioxidant activity of Pluchea indicia less leaves extracts. Int J Pharmacogn Phytochem Res. 6( 4 ): $850-855$. doi: $10.25258 / \mathrm{phyto}$. http://repository.wima.ac.id/id/eprint/10684.

Suhartati R, Apriyani F, Khusnul, Virgianti DP, Fathurohman M. 2019. Antimicrobial Activity Test of Mangosteen Leaves Ethanol Extract (Garcinia mangostana Linn) Against Pseudomonas aeruginosa Bacteria. J Phys Conf Ser. 1179(1). doi:10.1088/17426596/1179/1/012167.

Sulasmi S, Okid P, Astirin W, Tetri. 2020. Short Communication: The most active fraction of red turi flowers (Sesbania grandiflora) on the cytotoxic activity of HepG2 cells. Nusant Biosci. 12(1):68-72. doi:10.13057/nusbiosci/n120112.

Suyanti, Prabawati S, Sjaifullah. 2003. Sifat fisik dan komponen kimia bunga melati. Bul Plasma Nutfah. 9(2):19-22. doi:10.21082/blpn.v9n2.2003.p19-22.

Tahir M, Zainal Z, Darma D, Multi. 2017. Aktivitas Antioksidan Dan Karakteristik Organoleptik Minuman Daun Sukun (Artocarpusa altilis) Dengan Penambahan Bunga Melati (Jasminum sambac Ait.) [Antioxidan Activity and Organoleptic Characteristic of Bread Fruit (Artocarpus altilis) with Jasmine Addition Beverage (Jasminum sambac Ait.). J Agritech Sci. 1(2):1-11. doi: 10.30869/jasc.v1i2.126.

Tanaya V, Retnowati R, Suratmo. 2015. Fraksi semi polar dari daun mangga kasturi. Kim J. 1(1):778-784. doi: 10.21776/ub.jam.2021.019.03.01.

Thaweboon S, Thaweboon B. 2018. Antimicrobial activity of jasmine oil against oral microorganisms. IOP Conf Ser Mater Sci Eng. 307(1). doi: 10.1088/1757899X/307/1/012034.

Tuntun M. 2016. Uji Efektivitas Ekstrak Daun Pepaya (Carica papaya L.) terhadap Pertumbuhan Bakteri Escherichia coli dan Staphylococcus aureus.[Effectiveness Test of Papaya Leaf Extract (Carica papaya L.) on the Growth of Escherichia coli and Staphylococcus aureus. J Kesehatan. doi:10.26630/jk.v7i3.235.

Wang Y, Ding H, Xu X, Cheng D, Wang Z, Liu L. 2019. Antibacterial Effect of Plant Essential Oil on Bacillus subtilis. J Chinese Inst Food Sci Technol. doi:10.16429/j.1009-7848.2019.07.010.

Wardhani LK, Sulistyani N. 2012. Uji Aktivitas Antibakteri Ekstrak Etil Asetat Daun Binahong (Anredera scandens ( L .) Moq .) terhadap Shigella flexneri Beserta Profil Kromatografi Lapis Tipis Antibacterial Activity Test of Ethyl Acetate Extract Of Binahong Leaf ( Anredera scandens L). J Ilmu Kefarmasian. 2(1):1-16. doi: 10.12928/pharmaciana.v2i1.636.

World Health Organization. 1997. Methanol Health and Safety Guide. World Heal Organ. 105(105):1-31. http://apps.who.int/iris/bitstream/handle/10665/41944 19241511052_eng.pdf?sequence $=1 \&$ isAllowed=y.

Wu T, Zang X, He M, Pan S, Xu X. 2013. Structure-activity relationship of flavonoids on their anti- Escherichia coli activity and inhibition of DNA gyrase. J Agric Food Chem. 61(34). doi:10.1021/jf402222v.

Yilmaz MT. 2012. Minimum inhibitory and minimum bactericidal concentrations of boron compounds against several bacterial strains. Turkish J Med Sci. doi:10.3906/sag-1205-83.

Zuraida Z, Sulistiyani S, Sajuthi D, Suparto IH. 2017. Fenol, Flavonoid, dan Aktivitas Antioksidan Pada Ekstrak Kulit Batang Pulai (Alstonia scholaris R.Br). [Phenolics, Flavonoids, and Antioxidant Activity of Alstonia scholaris R.Br Stem Bark Extract]. J Penelitian Hasil Hutan. 35(3):211-219. doi:10.20886/jphh.2017.35.3.211-219. 